\title{
Die resente geskiedenis en ontwikkeling van die Departement Godsdiens- en Sending- wetenskap (Afd A), 1979-1992
}

\author{
P J van der Merwe
}

Universiteit van Pretoria

\begin{abstract}
Recent history and the development of the Department of Science of Religion and Missiology (Sec A), 19791992

The 'recent phase' in the history of this Department started with the author's appointment as Head in 1979. In his inaugural speech he recognised the need to restructure Science of Religion (within the Faculty of Theology) to the formal norms of theology. He visualised a theological Science of Religion which would reach its apogee in a theologia religionis and not a philosophy of religion. Recent history has seen changes in curricula to conform to Section A's curriculum reform project (which started in the early eighties). The Department even gained a subject - Evangelistics. This article gives an overview of teaching done since 1979. Current attempts to introduce Science of Religion to the Faculty of Arts, as a non-theological subject, are outlined.
\end{abstract}

\section{VOORAF}

Daar kan op meer as een grond betoog word vir die aparte behandeling van die resente geskiedenis van hierdie Departement. Uiteraard word dit verbind aan die feit 
dat skrywer hiervan in die plek gekom het van prof $\mathrm{F} J$ van $\mathrm{Zyl}$, wat aan die einde van 1978 afgetree het; tog is dit nie die vernaamste grond nie. Belangriker is die feit dat die metodologiese debat wat sedert die sestigerjare oor Godsdienswetenskap en teologie as sodanig gevoer is, nuwe denke en kurrikulêre verskuiwings meegebring het betreffende die saamgestelde vak, Godsdiens- en Sendingwetenskap, asook die ensiklopediese plek van Godsdienswetenskap in die teologiese opleiding.

Voorts is daar ook in die tagtigerjare begin met 'n projek van herkurrikulering in die Fakulteit Teologie (Afd A), wat teen die einde van die dekade ingrypende onderrigveranderings teweeggebring het.

Daar kom ook in hierdie tyd nuwe denke oor samewerking tussen die Departemente Godsdiens- en Sendingwetenskap van die twee teologiese fakulteite aan die Universiteit van Pretoria en die instelling van 'n nuwe vakkursus word beplan.

In hierdie artikel sal probeer word om 'n (evaluerende) oorsig te gee van hierdie ontwikkelings, asook 'n toekomsvisie met die oog op die komende rol van beide Godsdienswetenskap en Sendingwetenskap in die teologiese opleiding. Die artikel sluit af met 'n publikasielys van skrywer.

Hierdie artikel vorm die laaste in 'n reeks waaruit 'n volledige beeld van die Departement se geskiedenis en sy hoofde tot op datum blyk. Die ander artikels is (in logiese volgorde) die volgende:

Van der Merwe, P J \& Crafford, D 1992. 'n Oorsig van die geskiedenis van die Departement Godsdiens- en Sendingwetenskap (Afd A), Universiteit van Pretoria 1917-1978. (In hierdie feesuitgawe opgeneem.)

Van Zyl, F J 1992. Die lewe en werk van prof dr H P Wolmarans in hooftrekke. (Ook in hierdie feesuitgawe.)

Van der Merwe, P J 1989. Prof dr F J van Zyl as mens, kerkman en godsdiensfilosoof. HTS 45, 231-252.

Van Wyk, D J C 1989. Prof dr F J van Zyl as sendingteoloog. HTS 45, 263-279.

Geyser, P A 1989. Prof dr F J van Zyl se Skrifbeskouing. HTS 45, 253-262.

Van Wyk, D J C 1978. Sendingteorie en sendingpraktyk in die Nederduitsch Hervormde Kerk: verlede, hede en toekoms. HTS 43, 99-120.

\section{PERSONEELBESETTING}

Die jongste periode in die geskiedenis van hierdie Departement begin in 1979 met die aanstelling van prof $\mathbf{P} \mathrm{J}$ van der Merwe (BA Hons, DD, Dip Ters Ond [Pret]) as hoof. Hy voltooi sy BD-opleiding in 1968 en promoveer in 1977. Hy is in 1970 as deeltydse predikant georden in die gemeente Premiermyn. In die tydperk 19711978 doseer hy as senior-lektor die vak Godsdienswetenskap aan die teologiese 
fakulteit van UNISA en parallel daarmee tree hy as deeltydse predikant op, eers in die gemeente Premiermyn en in 1972-1978 in Witfontein (Pretoria-Noord).

As tydelik-deeltydse dosente het drr C J Viljoen en D J C van Wyk vanaf 1979 tot 1988 in die Departement gedien. Dr H G van der Westhuizen het vanaf 1978 as tydelik-deeltydse dosent gedien tot 1979 toe hy na Pietersburg vertrek met sy aanstelling aan die Universiteit van die Noorde. Dr Viljoen het versoek om na 1989 nie weer in diê hoedanigheid aangestel te word nie. Vanaf 1989 dien $D \mathrm{~J} C$ van Wyk, E Engelbrecht, H G van der Westhuizen en J D Gericke in tydelik-deeltydse hoedanigheid.

\section{ENKELE BELANGRIKE VERSKUIWINGS}

Godsdienswetenskap en die metodologiese debat

Gedurende die sewentigerjare begin die metodologiese debat in alle erns oor die aard en plek van die Godsdienswetenskap. Dit is 'n debat wat vandag nog nie uitgewoed is nie, hoewel dit nou heelwat rustiger gaan as vroeër. Uiteraard is die verhouding met teologie ook onder die vergrootglas geplaas en moes die vraag weer eens gevra word wat teologie in werklikheid is.

Die algemene neiging in die debat was om Godsdienswetenskap as selfstandige vak binne die raamwerk van Lettere en Wysbegeerte te definieer en 'n duidelike onderskeid tussen die vak en teologie te stel.

Prof Van der Merwe wy sy intreerede aan die vraag na die plek van Godsdienswetenskap in die Fakulteit Teologie en in die teologiese opleiding. Hy gee toe dat die klassieke Godsdienswetenskap eintlik nie binne die Fakulteit Teologie hoort nie, maar pleit dan nogtans vir 'n teologiese Godsdienswetenskap wat sy hoogtepunt vind in ' $n$ theologia religionis, dit wil sê ' $n$ teologiese besinning oor en na aanleiding van die verskynsel 'godsdiens' (in teenstelling met theologia religionum wat 'n teologiese besinning oor en na aanleiding van die onderskeie historiese godsdienste behels en wat deur sommige ensiklopedici tot die Sendingwetenskap gereken word). Godsdiens as verskynsel hou 'n fundamentele vraagstelling vir die héle teologie in en daarom is dit verkeerd om te dink dat slegs die Sendingwetenskap waarde van hierdie vak het. Hy wil dus 'n Godsdienswetenskap in die teologiese fakulteit sien wat bewustelik teologie wil wees (Van der Merwe 1979). In 'n artikel wat in 1985 in die Henormde Teologiese Studies verskyn het, word dieselfde gedagte nog duideliker uitgespel (Van der Merwe 1985).

Dit het beteken dat die bestaande vak omvorm en met heelwat nuwe vraagstellings en inhoude gevul moes word. In die leerplanne word daarna verwys as 'Teologiese Godsdienswetenskap'. 
Daar is vanaf 1979 begin om nuwe leerplanne in te faseer. Wat die Teologiese Godsdienswetenskap betref, sou Godsdiensgeskiedenis en Godsdiensfenomenologie in BD 1 aangebied word. In beide gevalle word godsdiensteologiese vraagstellings op 'n geïntegreerde wyse hanteer. In BD 2 word op theologia religionis religionumque gekonsentreer en in BD 3 op Teologiese Godsdiensfilosofie. Daar is ook besluit om die ideologieë in oorsig te neem. Aanvanklik is dit in die derde jaar geakkommodeer.

Die naam 'Teologiese Godsdiensfilosofie' is ' $n$ aanduiding dat ook hier ' $n$ verandering plaasgevind het. Die tradisionele Godsdiensfilosofie soos deur MacMillan beoefen, kon net sowel in die Fakulteit Lettere en Wysbegeerte beoefen gewees het. Met Godsdienswetenskap het dit ook nie veel te doen gehad nie. Die soort Godsdiensfilosofie wat Brunner en Mann later voorstaan, vind op sy beurt weer nouer aanklank by die Sistematiese Teologie as by die Teologiese Godsdienswetenskap. Dit was duidelik dat as 'n godsdiensfilosofie in hierdie Departement geakkomodeer moes word, dit met inhoude gevul moes word wat aansluiting vind by die Teologiese Godsdienswetenskap. Daarom word die subvak herstruktureer as een waarin dit primêr om theologia religionis handel, dit wil sê om 'n teologiese teoretisering oor die verskynsel 'godsdiens' en die implikasies daarvan vir die teologie en die kerk. Verder gaan dit ook om metodologiese besinning oor die vak self.

\section{Sendingwetenskap}

Met Sendingwetenskap is grootliks voortgegaan op die weë wat deur prof Van Zyl gebaan is. Die basiese dilemma waarmee die onderrig van die vak in hierdie Departement te doen het, is dat die sendingbeleid van die Nederduitsch Hervormde Kerk enige kans uitskakel dat kandidate as sendelinge onder swart volke uitgestuur kan word. Aan die ander kant bestaan daar 'n missionêre struktuur en praktyk waarby ringsendingsuperintendente inskakel.

Met die Sendingwetenskap is die skema gevolg dat Teologie van die Sending in BD 1, Sendinggeskiedenis in BD 2 en praktiese vraagstellings in BD 3 geplaas is.

\section{'n Nuwe subvak word bygevoeg}

'n Vak wat in die tagtigerjare bygevoeg sou word, is Evangelistiek. Met die toenemende belangstelling in die kerk vir evangelisasie, het daar uit baie oorde aandrang gekom dat die vak Evangelistiek in die teologiese opleiding geakkommodeer moet word. In ongeveer 1981 is in samesprekings met prof J I de Wet, die destydse hoof van die Departement Praktiese Teologie, ooreengekom oor samewerking tussen sy 
en hierdie Departement oor die aanbieding van die vak. Ongeveer drie jaar later is besluit om die vak geheel en al deur Praktiese Teologie te laat aanbied. Die Dosentevergadering het egter in 1988 besluit dat Evangelistiek 'n apostolêre vak is en daarom in die geheel by die Departement Godsdiens- en Sendingwetenskap hoort. Dit word dan ook sedert 1989 as deel van die vyfde- en sesdejaarskursusse aangebied.

\section{Die Departement en herkurrikulering}

Die Fakulteit Teologie (Afd A) begin in die tagtigerjare met ernstige herkurrikulering - een van die eerste Fakulteite aan die Universiteit om dit op 'n wetenskaplike en deurtastende wyse te doen. Prof van der Merwe is tot voorsitter van die Kurrikulum-komitee verkies en dien in dié hoedanigheid totdat die dekaan, prof J P Oberholzer, die voorsitterskap in 1989 in ooreenstemming met die riglyne van die Afdeling Onderrigontwikkeling oorneem.

Die herkurrikuleringsprojek het uitgegaan van die volgende twee vrae:

- Waarop is die teologiese opleiding gemik? Hoe moet die teologiese kandidaat by afstudering daar uitsien? Oor watter persoonlike en beroepskwaliteite moet hy/sy beskik?

- Watter inhoude en onderrigmetodes dien hierdie oogmerke die beste?

Dit het duidelik geword dat die semi-outonome bestaan wat departemente vroeër gevoer het, grootliks tot 'n einde gekom het. Die teologie is 'n geïntegreerde saak en elke departement, elke vak maak wat die BD-opleiding betref, deel uit van 'n spanpoging waarvan die uiteindelike oogmerk is om die bes moontlik opgeleide en gevormde kandidaat vir die bediening daar te stel.

Aan die ander kant moes elke departement ook nog sy plek aan die Universiteit en in die wetenskaplike gemeenskap volstaan en moes daar dus ook met wetenskaplike norme, vereistes en verwagtings rekening gehou word.

Anders as in ander fakulteite, val die behoeftes van die beroepspraktyk en die wetenskap nie in ons geval noodwendig saam nie. Trouens, die teologie word in sommige kerklike kringe selfs as afbrekend ten opsigte van die geloof beskou. Dit plaas 'n ongemaklike spanning op die teologiese opleiding - menige teologiese dosent moes al hoor dat 'n bepaalde vakinhoud irrelevant of selfs ondermynend ten opsigte van die bediening sou wees.

Hoe dit ook al sy, die leerplanne van hierdie Departement in die drie BD-kursusjare, het, na hersiening in 1989 , soos volg daar uitgesien: 


\section{GSW400 Godsdiens- en Sendingwetenskap 1}

GSW410 Inleiding in die Teologiese Godsdienswetenskap.

GSW420 Godsdiensgeskiedenis: Hier word sake soos Boeddhisme, Hindoeïsme, Islam, godsdienste van Afrika, nuwe godsdienste ensovoorts inleidend en oorsigtelik bestudeer.

GSW430 Godsdiensfenomenologie: 'n inleidende en oorsigtelike studie.

GSW440 Inleiding in die Sendingwetenskap.

GSW450 Teologie van die Sending: fundering, oogmerke en doel; historiese oorsig.

GSW500 Godsdiens- en Sendingwetenskap 2

GSW510 Teologie van die godsdienste.

GSW520 Teologie en ideologie.

GSW530 Inleiding in die Evangelistiek.

GSW540 Sendinggeskiedenis.

GSW600 Godsdiens- en Sendingwetenskap 3

GSW610 Teologiese Godsdiensfilosofie: Hier word sake soos Fundamentele Godsdienswetenskap, Teologie van die godsdiens en gesprek met ander vorme van godsdiensfilosofie hanteer.

GSW620 Fenomene, aktualiteite en tendense wat kerk en teologie raak: 'n omnibusmodule waarin sake soos sekularisasie, burgerlike godsdiens en kommunikasie en beïnvloeding hanteer word.

GSW630 Teologiese en praktiese vraagstellings in die Evangelistiek.

GSW640 Kerk en sending - onderverdeling: Seleksie van algemene temas, die apostolaat in die Kerkwet en Bepalings en seleksie van aktuele en praktiese aangeleenthede in die sending van die Nederduitsch Hervormde Kerk.

Die Jaarboek 1988 is die eerste om die regulasies met betrekking tot die nuwe MDiv-graad te bevat (wat in die plek van die ou doktorale eksamen gekom het). Daarin word Groep E, die Godsdiens- en Sendingwetenskaplike Groep se leergang bloot beskryf as: (i) Godsdienswetenskap en (ii) Sendingwetenskap. Die leerplanne van Afdeling A se MDiv- en DD-kursusse en nadere uiteensetting daarvan word nou opgeneem in 'n Handleiding vir Nagraadse Studie waarvan die eerste uitgawe in 1988 en die tweede in 1990 verskyn het. 


\section{ONDERRIG}

Die stelsel van voorgeskrewe boeke kom in die tagtigerjare onder druk van boekhandelboikotte en hoë pryse. Laasgenoemde lei daartoe dat studente begin om boeke of dele van boeke te fotostateer in plaas daarvan om dit aan te koop, 'n praktyk wat die boekhandel ook van die duskant onder druk plaas. In die onseker voorsieningsituasie wend dosente hulle tot minder voorgeskrewe werk en meer uitgebreide 'kernaantekeninge', totdat dit aan die einde van die dekade vir die Universiteit 'n ondraaglike las begin word. Dit lei tot die konsep van studiehandleidings, wat die klem terugplaas op voorgeskrewe en aanbevole publikasies, hierdie keer in samewerking met die Gereserveerde Studieversameling van die Merensky-Biblioteek. Boekvoorsiening het intussen verbeter, alhoewel boekpryse vanweë die ongunstige wisselkoers hoog bly.

Die Departement begeef hom in 1990 ook op die gebied van lessenaarpublikasies toe die boek, Kerk en kerstening, van die pen van prof $\mathbf{H ~ G}$ van der Westhuizen in die Departement persklaar gemaak en in samewerking met KITAL uitgegee is. Die boek is bedoel om as handboek in hierdie Departement en by die Hervormde Teologiese Opleiding (Klipdrif) gebruik te word. In 1991 is 'n boek van die Raad vir Godsdienste, te wete Ons Joodse bure, op dieselfde wyse versorg en uitgegee.

Afdeling A verhuis in 1981 vanaf die geliefde Ou Lettere-gebou na die Nuwe Lettere-gebou, wat vanaf dieselfde jaar herdoop is na die Teologiegebou. Skielik was oorhoofse-projeksiegeriewe beskikbaar, asook ruim seminaarkamers. Kursusse is deur die Afdeling Onderrigontwikkeling vir dosente aangebied wat hulle moes toerus om van die nuwe geriewe gebruik te maak.

Met die sogenaamde Espada-beraad wat die Dosentevergadering in 1988 gehou het, is besluit om nie alleen die herkurrikuleringsprojek af te handel nie (wat op daardie stadium in elk geval byna voltooi was), maar ook met die Afdeling Onderrigontwikkeling saam te werk met die implementering van doelmatige onderrigstrukture, -geleenthede en -metodes. Daar is in 1989 dan ook begin met minder lesings, meer seminare en die doelgerigte implementering van studiehandleidings.

Vanaf 1979 is onder andere die volgende werke vir die BD-studie voorgeskryf: E Nida (1960) Message and mission, J H Bavinck (1964) Introduction to science of mission, H Ringgren \& A V Ström (1967) Religions of mankind-today and yesterday, G Widengren (1969) Religionsphänomenlogie, D J Bosch (1974) Het evangelie in Afrikaans gewaad, T P Burke (1974) The reluctant vision, H G Hubbeling (1976) Denkend geloven, S Neill (1977) Christian faith and other faiths, G C Oosthuizen (1977) Die godsdienste van die wêreld, J Verkuyl (1978) Contemporary missiology, J Verkuyl (1978) Inleiding in de evangelistiek, D J Bosch (1979) Heil vir die wêreld, T P Burke (1979) The fragile universe, J J De Klerk (red) (1979) Evangelistiek, H G Van 
der Westhuizen (1981) Volkskerk en sending, J S Krüger (1982) Studying religion, A Glasser \& D MacGavran (1983) Contemporary theology of mission, W S Vorster (red) (1983) Church and industry, D Allen (1985) Philosophy for understanding theology, J Hick (1985) Problems of religious pluralism, G D'Costa (1986) Theology and religious pluralism, J Leatt et al (eds) (1986) Contending ideologies in South Africa, W P Esterhuysen (red) (1987) Modeme politieke ideologie, H L Pretorius et al (1987) Reflecting on mission, D Crafford (1988) Uitdagings vir die kerk in Afrika, J J Kritzinger (1988) Die onvoltooide sendingtaak in Suid-Afrika, J J Kritzinger (1988) You will be my witnesses, M Van Campen (1989) Kerk en Israel in gesprek en $\mathbf{H ~ G}$ Van der Westhuizen (1990) Kerk en kerstening.

In 1991 maak 'n verdere vernuwing sy verskyning: onderrig van kursusse in sesweeklange blokke met eksamen aаn die einde van elke blok.

Die volgende persone promoveer in hierdie tydperk: P B Boshoff (oorgedra vanaf prof Van Zyl), T F J Dreyer, J A Beukes (met prof Van der Merwe as medepromotor) en $\mathbf{E}$ Engelbrecht. Nog 'n kandidaat is tans met sy proefskrif besig.

\section{ANDER SAKE}

\section{Voortgesette Teologiese Toerusting}

Hiermee is in 1990 begin as nog 'n vrug van die kurrikulumondersoek van die Dosentevergadering. Die verskillende departemente is saamgegroepeer in vier groepe met KITAL as vyfde groep. Die onderrigstruktuur volg siklusse van vyf jaar. Kerkgeskiedenis, Godsdiens- en Sendingwetenskap vorm saam Groep 3 en handel in die eerste siklus oor die parallelle temas (1) Kerk, opsig en tug, en (2) Kerk, evangelisasie en die evangelisasiegesprek. Groep 3 het besluit om op praktiese vraagstellings te fokus en die besondere onderrigsituasie wat geld, innoverend uit te baat.

Die reaksie van predikante wat die eerste vier kursusse deurloop het, was besonder positief. Kursusgangers is telkens na afloop van die kursus versoek om die kursus te evalueer en aan die hand daarvan word voortdurend verstellings aangebring. Heelwat is geleer en sekere insigte het intussen ook in die BD-onderrig toepassing gevind.

\section{Rasionalisasie}

Die nuwe ekonomiese bestedingsplan van die staat en die afplatting in die land se ekonomiese groei, gekoppel aan die vooruitsig van 'n afname in teologiese studentegetalle in die negentigerjare, het die Fakulteit, saam met die Universiteit, genoop 
om ernstige oorweging aan optimalisasie en rasionalisasie te verleen. Hierdie debat wat aan die einde van die tagtigerjare begin het, sal nog lank nie afgehandel wees nie. Die eerste rasionalisasiebesluit wat geneem is, was om die program om in elke departement ' $n$ tweede doseerpos te skep, te kanselleer. (Die Departement Godsdiens- en Sendingwetenskap (Afd A) was geoormerk om ná Praktiese Teologie 'n tweede doseerpos te kry.)

'n Verdere moontlikheid wat oorweeg is, was om die aantal departemente in die fakulteitsafdeling van ses na vier te verminder. Volgens dié voorstel sou die Departemente Ou-Testamentiese- en Nuwe-Testamentiese Wetenskap saamsmelt, terwyl die Departement Godsdiens- en Sendingwetenskap sou verdwyn - Sendingwetenskap sou by die Departement Praktiese Teologie gevoeg word en Teologiese Godsdienswetenskap sou by die Departement Kerkgeskiedenis of Dogmatiek en Christelike Etiek ingedeel word. By die Espada-beraad is die moontlikhede van alle kante bekyk. Nadat vasgestel is dat die ekonomiese voordele van so 'n stap minimaal sou wees, is besluit om nie hierdie ingrypende stap te neem nie.

Intussen het die rasionalisasiedruk op die Fakulteit toegeneem. Die bestaan van twee fakulteitsafdelings wat mekaar dupliseer, word nie deur universiteitsowerheidsinstansies en ander fakulteite in 'n gunstige lig gesien nie. Die vraag word gevra of daar nie ten minste sekere onderrigvelde of -temas geïdentifiseer kan word wat gemeenskaplik gedoseer kan word nie. Van der Merwe het hierdie vraag reeds in 1982 gevra toe hy ' $n$ lesing by 'n Teologiedag wat saam deur die twee fakulteitsafdelings aangebied is, gelewer het. Hy het toe voorgestel dat die twee fakulteitsafdelings met mekaar ooreenkom om kursusse en lesings te rasionaliseer, spesialiteitsterreine af te baken en in die algemeen nouer met mekaar saam te werk (Van der Merwe 1983:74). So 'n rasionalisasiestap sou dit moontlik maak om onderrigkragte beter aan te wend en sou spesialisasiemoontlikhede open.

Vroeër is reeds ' $n$ memorandum aan die Departement Godsdiens- en Sendingwetenskap (Afd B) oorhandig waarin spesifieke voorstelle in dié verband gedoen is. Dit het gelei tot die stigting van 'n vakkomitee tussen die twee departemente Godsdiens- en Sendingwetenskap wat steeds funksioneer. Nadat prof D Crafford in 1989 die hoof van die Departement Godsdiens- en Sendingwetenskap (Afd B) geword het, het samewerking tussen die twee departemente nuwe momentum gekry en vanaf die begin van 1990 word daar dan ook op beskeie skaal onderrigkragte uitgeruil. Veral op die gebied van die Godsdienswetenskap is daar onnodige oorvleueling tussen die twee departemente. Beplanning is tans aan die gang om deur koördinering van die leerplanne en rooster tot 'n gesamentlike aanbieding van die vakgebied te kom. 
'n Verdere rasionalisasiemoontlikheid wat tans ondersoek word, is onderrigsamewerking tussen die Departement Godsdiens- en Sendingwetenskap (Afd A) en die Hervormde Teologiese Opleiding (HTO) te Klipdrif, 'n instansie met wie so 'n verhouding ook natuurlik is. Die HTO verteenwoordig 'n korps van sendingwetenskaplike kundigheid wat hierdie Departement net tot sy skade kan ignoreer. Die Departement is daarom dankbaar om reeds van die dienste van proff $E$ Engelbrecht en $\mathrm{H} \mathrm{G}$ van der Westhuizen as tydelik-deeltydse dosente gebruik te kan maak.

Verhoudinge met ooreenstemmende departemente aan ander universiteite Met die Departement Godsdienswetenskap en die Departement Sendingwetenskap te UNISA word daadwerklike verhoudinge gehandhaaf in die vorm van eksterne eksaminering - daar en hier - tot op proefskrifvlak. Daar is ook gereelde kontak op vakkundige terrein.

Voorts tree prof Van der Merwe ook etlike jare reeds op as eksterne eksaminator in die vak Godsdienswetenskap aan die Universiteit van die Noorde.

Kontak met ander teologiese fakulteite of departemente Godsdienswetenskap geskied via die onderskeie werkgemeenskappe, te wete die Suider-Afrikaanse Werkgemeenskap vir Sendingwetenskap en die Association for the Study of Religion (Southern Africa), beide waarvan prof Van der Merwe lid is.

\section{Godsdienswetenskap in Lettere en Wysbegeerte}

'n Saak wat etlike jare gelede in die vakkomitee te berde gebring is, is die instelling van 'n vak Godsdienswetenskap wat op BA-vlak vanuit die Fakulteit Teologie in die Fakulteit Lettere en Wysbegeerte aangebied word. So 'n vak sal godsdiens hanteer as algemeen menslike verskyningsvorm en dus 'n nie-teologiese benadering volg. Dit volg op verskeie navrae wat vroeër reeds van geïnteresseerde studente ontvang is. Gedurende 1990 is daadwerklik met beplanning en samesprekings begin en dit het nou 'n fase bereik waarin dit lyk of implementering vanaf begin 1994 voorspel kan word.

Die onderrig van die vak sal op 'n multidissiplinêre wyse geskied en toepaslike departemente in die Fakulteit Lettere en Wysbegeerte sal betrek word. Die wyse waarop die instelling van die vak voorsien word, is rasionaliserend deurdat van bestaande kundigheid gebruik gemaak word. Die vak sal bestuur word deur 'n vakkomitee waarop deelnemende departemente sitting sal hê. Hierdie verwikkeling verteenwoordig waarskynlik die vernaamste ontwikkeling sedert daar in 1917 met die onderrig van Godsdienswetenskap begin is. 


\section{Navorsing}

Tydens die Algemene Kerkvergadering van 1986 is besluit om met 'n studieprojek na die apostolaat van die Nederduitseh Hervormde Kerk te begin. So 'n projek is dan ook in die volgende jaar by die RGN geregistreer onder die vaandel van hierdie Departement. Hoewel die aanvanklike vordering maar traag was, kan die huidige vordering as bestendig getipeer word en word groot verwagtinge van die projek gekoester.

\section{EVALUERING}

By so 'n terugskou bestaan daar nie alleen dankbaarheid vir positiewe ontwikkelinge die afgelope veertien jaar nie, maar ook 'n besef van swakplekke en gebreke. 'n Belangrike probleem (wat ook vir elke ander lid van hierdie fakulteitsafdeling geld) is die druk van verwagtinge op die dosent vanaf Universiteit en kerk. Van Universiteitskant word van die dosent verwag om in 'n dikwels relatief-krimpende mannekragsituasie te presteer op die terreine van onderrig, navorsing, gemeenskapsdiens, administrasie en bestuur, terwyl die teologiese professore in die kerk steeds gesien word as onontbeerlike spesialiste wat op kommissies en rade moet dien en gereeld adviesstukke moet opstel. So 'n toestand lei onafwendbaar daartoe dat sekere terreine afgeskeep word en gewoonlik is dit daardie terreine waarvan die agteruitgang eers oor die langer termyn sigbaar word, soos navorsing.

'n Tweede swakplek wat hiermee verband hou, is die hantering van die dubbele druk van oorsigtelikheid en spesialisasie in wetenskaplike kompetensie. Godsdienswetenskap en Sendingwetenskap is duidelik twee afsonderlike vakgebiede, elkeen met sy eie momentum en ontploffende vakliteratuur. Tensy daar op een of ander manier 'n vorm van samewerking tussen hierdie (eenman-)departement en die instansies hierbo genoem, tot stand kom, sal die probleem nie hanteer kan word nie. Terwyl daar groot dankbaarheid is vir tydelik-deeltydse doseerhulp en daar nie meer sonder hulle gefunksioneer kan word nie, bied dit nie 'n vaste basis vir die hantering van hierdie probleem nie.

'n Derde swakplek in die prestasie van hierdie Departement gedurende sy lang geskiedenis is dat nie juis daarin geslaag is om 'n belangstelling vir Sendingwetenskap op post-BD-vlak op te wek nie. Aan die ander kant het etlike BD 3-studente darem oor die jare heen gekies om hulle skripsies oor 'n sendingwetenskaplike onderwerp te skryf en kan nie beweer word dat die vak geen belangstelling in die kerk geniet nie. 'n Strategie is dus nodig om hierdie probleem in die toekoms reg te stel. 


\section{SLOT EN TOEKOMSVISIE}

Dit is nie toevallig dat hierdie Departement een van die oudstes in die Fakulteit Teologie is nie. Hoewel Karl Barth godsdiens per implikasie tot een van die minder belangrike vraagstellings van teologie verklaar het (Barth 1960:323), het die geskiedenis van die teologie anders beslis. Dit is een van die fundamentele teologiese vraagstellings. So was dit in 1917 tydens die stigting van die Fakulteit en so is dit ook in 1992 met die vyf en sewentigjarige herdenking. Met die toenemende godsdienstige pluraliteit sal dit in die voorsiene toekoms nog meer so wees. Dit maak'n teologiese godsdienswetenskap onontbeerlik in 'n teologiese fakulteit en enige teologiese opleiding.

Oor die bestaansreg van Sendingwetenskap en Evangelistiek hoef seker nie betoog te word nie, hoewel die een op 'n gegewe stadium meer aktueel as die ander mag wees. Waar die oorwig in die geskiedenis van hierdie Departement onteenseglik ten gunste van Godsdienswetenskap gegeld het, het 'n subtiele verskuiwing in die teenoorgestelde rigting oor ongeveer die afgelope tien jaar merkbaar geword. Dit weerspieël die nuwe belangstelling in die kerk vir die apostolaat, 'n neiging wat net toegejuig kan word.

\section{NASKRIF}

Waar hierdie gedenkbundel ook 'n feesbundel is wat aan ons afgetrede dekaan, prof J P Oberholzer, opgedra word, moet die geleentheid te baat geneem word om hom seënwense en voorspoed op sy verdere lewensbaan toe te wens. Die samewerking met hom op verskillende vlakke was altyd vrugbaar en aangenaam en boonop het hy hom by meer as een geleentheid as ' $n$ vriend van hierdie Departement bewys. Hy beskik oor die vermoë om hom so geheel en al aan sy werkkring toe te wy dat hy later die vernaamste simbool daarvan word. Hy het ons ook beïndruk met sy energie, daadkrag en verbeeldingrykheid. Daarom word met belangstelling gewag om te sien hoe hy sy aftrede as 'n nuwe geleentheid gaan benut. 


\section{Literatuurverwysings}

Barth, K 1960. Kirchliche Dogmatik I/2 (5e oplaag). Zollikon-Zürich: Evangelischer Verlag.

Van der Merwe, P J 1979. Die godsdiens as probleem vir die Godsdienswetenskap en die teologie. Pretoria: Universiteit van Pretoria.

-- 1983. Die BD-graadkursus aan UP en die keuse tussen teologiese- of predikantsopleiding - 'n blik vanuit die Nederduitsch Hervormde Kerk. Skrif en kerk 4/1, 69-74.

--- 1985. Die godsdienswetenskaplike aspek van teologie. HTS 41/4, 511-518.

Publikasies van prof P J van der Merwe

Proefskrif

1977. Die godsdienste by Vaticanum II. Pretoria: Universiteit van Pretoria. (Ongepubliseerd.)

Dele van boeke of brosjures

1978. Godsdienswetenskap, in Eybers, I H (red), Inleiding in die teologie. Pretoria: NG Kerkboekhandel.

1979. Die godsdiens as probleem vir die Godsdienswetenskap en die teologie. Pretoria: Universiteit van Pretoria.

1981. Burgerlike godsdiens in Suid-Afrika - teologies en godsdienswetenskaplik beskou, in Botha, S J, Kerk in die wêreld. Pretoria: HAUM.

1981. Response to J S Krüger, The concept religion a dimensional clarification. Proceedings of the 5th Symposium of the Institute for Theological Research. Pretoria: UNISA.

1986. Les 26: Die Islam. Leer hulle 7, 176-180. Pretoria: KITAL.

1986. Les 43: Judaïsme, Islam en Hindoeïsme. Glo die Woord, 224-228. Pretoria: KITAL.

1991. Die New Age-beweging. (Saam met J Buitendag). Vereeniging: Christelike Uitgewersmaatskappy.

1991. Sionisme en die staat Israel, in Van Wyk, W C (red), Ons Joodse bure. Pretoria: KITAL.

Artikels in die Hervormde Teologiese Studies

1984. Die teologiese opleiding en kurrikulumondersoek. HTS 40/1, 141-146.

1984. Doop, sending en die opkoms van die juridiese kerkbegrip. HTS 40/3, 62 67. 
1985. Die godsdienswetenskaplike aspek van teologie. HTS 41/4, 511-518.

1986. RGN-Verslag oor godsdiens, tussengroepverhoudinge en maatskaplike verandering in Suid-Afrika. HTS 42/3, 564-579.

1987. Die wonder en wondervertelling gesien teen die agtergrond van mite en ontmitologisering. HTS $43 / 1 \& 2,192-204$.

1989. Paradigmas en progressie in die teologie: 'n perspektief op die RGN-kongres van April 1988. HTS 45/2, 476-507.

1989. Prof dr F J van Zyl as mens, kerkman en godsdiensfilosoof. HTS 45/2, 231252.

1990. Die Nederduitsch Hervormde Kerk en sy bediening in 'n toekomstige SuidAfrika: Die visie van 'Kerk en wêreld 2000'. HTS 46, 672-689.

\section{Artikels in Die Henormer}

1973. 'n Nuwe kerkgebou vir die Bantoe Hervormde Kerk te Ghataan, Sekoekoenieland. Die Hervormer 63/11, bl 14.

1973. Die selfstandigwording van jong kerke: Biskop Crowther en die Nigeriese Anglikaanse Kerk. Die Hervormer 64/7, bl 12-13.

1973. Die selfstandigwording van jong kerke: Die Presbiteriaanse Kerk in Korea. Die Hervormer 64/5, bl 9-10.

1973. Die selfstandigwording van jong kerke: Die Lutherse Batakkerk. Die Hervormer 64/6, bl 9-10.

1973. Die selfstandigwording van jong kerke: Die Baptiste-Karenkerk in Burma. Die Henormer 64/8, bl 8-9.

1973. Joga - tegniek tot selfverlossing (Deel 1). Die Hervormer 64/4, bl 27-28.

1973. Joga - tegniek tot selfverlossing (Deel 2). Die Hervormer 64/5, bl 15-16.

1973. Joga - tegniek tot selfverlossing (Deel 3). Die Hervormer 64/6, bl 14-15.

1977. Die kerk en die nie-Christelike godsdienste. Die Hervormer 68/1, bl 9.

1977. Verbrokkelende huwelike. (Berig oor voordrag van prof F J van Zyl.) Die Henormer 68/2, bl 8.

1978. 'n Belydenisskrif teen apartheid? Die Hervormer 70/7, bl 11, 12.

1979. Is wen net voorbly? Die Henormer 71/9, b1 4.

1979. Kerk, owerheid en politiek. Die Hervormer 71/9, b1 6.

1980. Dokumenteksegese of Bybeleksegese. Die Hervormer 71/12, bl 24.

1980. Falsche Eindrücke was burgerliche Religion anbetrifft. Nachrichtenbrief von Die Hervormer 1/1, bl 2.

1980. Verskillende vertolkings van die Kerkhervorming. Die Hervormer 72/7, bl 4.

1981. Diensformuliere: Hersiening noodsaaklik. Die Henormer 73/1, bl 16. 
1981. Fundamentalisme as 'n struikelblok in die teologiese en ekumeniese diskussie. Die Hervormer 73/10, bl 16.

1981. Is die spreke in tale Christelik? Die Hervormer 74/1, Bylae Studente-Hervormer 18 , bl 3.

1981. Die totstandkoming van afsonderlike teologiese fakulteitsafdelings aan UP. Die Henormer 74/7, bl 16.

1983. Sestigste Algemene Kerkvergadering - 'n terugblik. Die Henormer 75/3, bl 4.

1984. Oordenking: Ons eerste bekommernis vir 1984. Die Hervormer 75/10, bl 8 .

1984. Waarom kinders doop? Die Hervormer 75/11, bl 1.

1984. Die bokramsatan. Die Henormer 75/11, bl 5.

1985. HTV besin oor gelykenisse. Die Henormer 77/6, bl 16 .

1985. HTV in diens van teologie en kerk. Die Hervormer 77/6, bl 16.

1986. Prof JA Stoop tree af. Die Henormer 77/10, bly 2.

1986. Ons Hervormers moet meer so bymekaarkom. Die Hervormer 78/1, bl 13.

1986. HTV praat oor liturgiese vernuwing. Die Hervormer 78/3, bl 3.

1986. Artikel III bly onveranderd, maar die studie gaan voort. Die Hervormer $78 / 4$, bl 5 .

1987. Christelike medeverantwoordelikheid vir 'n skoner Suid-Afrika. Die Hervormer 78/10, bl 3.

1988. Evangelisasie 'n venster aan buitestaanders. Die Hervormer 80/1, bl 16.

1988. Lyding van Christus en die lyding van mense. Die Hervormer 79/12, bl 1.

1988. Ons gehoorsaamheid aan die groot opdrag. Die Hervormer 80/7, Bylae Jong-Hervormer 95, bl 1, 3 .

1988. Verband tussen die Skepping en die kinders van God (Rom 8:18-23). Die Hervormer 80/6, Bylae Vroue-Hervormer 95, bl 3.

1989. Fakulteitsopening lui nuwe tydperk in. Die Hervormer 80/12, bl 16 .

1989. Word alle goeie en vroom mense gered, of net diegene wat in Christus glo? Die Hervormer 81/6, bl 9.

1989. Volkskerk - kerk van Christus. Die Hervormer 81/7, bl 5, 13.

1990. Augustinus: Kerkvader van Noord-Afrika (1). Die Hervormer 82/5, bl 8.

1990. Augustinus: Kerkvader van Noord-Afrika (2). Die Hervormer 82/6, bl 8.

1990. Augustinus: Kerkvader van Noord-Afrika (3). Die Hervormer 82/7, bl 8.

1990. Dosente hou bosberaad. Die Henormer 82/13, bl 1.

Reeks in Die Hervormer

'Ons lees in Die Hervormer van...': vanaf 1989, 81/3, tot 1991, 83/5. 
Artikels in ander tydskrifte

1973. Die krisis in die moderne Godsdienswetenskap. Theologia evangelica 6/1, 56-68.

1976. Die Christendom in die wêreldgeskiedenis. Theologia evangelica $9 / 2$ \& 3 , 187-194.

1978. Die uitspraak van die Tweede Vatikaanse Konsilie oor die Jode - 'n kommentaar. Deel 1. Theologia evangelica 11/1, 62-71.

1978. Die uitspraak van die Tweede Vatikaanse Konsilie oor die Jode - 'n kommentaar. Deel 2. Theologia evangelica 11/2 \& 3, 34-41.

1981. Nihilisme, naïewiteit en ideologie. Antikom November 1981.

1983. Die BD-graadkursus aan UP en die keuse tussen teologiese - of predikantsopleiding - 'n blik vanuit die Nederduitsch Hervormde Kerk. Skrif en kerk 4/1, 69-74.

1986. Die Islam as godsdiens en groepering. Bybel en volk 2/5, 13-16.

1986. Die Islam en die Christendom. Bybel en volk 2/4, 5-8.

1990. Die Turynse kleed. Konteks 1/1, 14-15.

Boekbesprekings

1972. Voipio, R. Algemene godsdienskunde. Theologia evangelica 5/2, 153-154.

1973. Bleij, W 1973. Kinderdiensten. Theologia evangelica 6/1, 78-79.

1973. Sperna Weiland, J 1971. Oriëntasie. Theologia evangelica 6/3, 233.

1973. Zaehner, R C. Concordant discord. Missionalia 1, 35.

1975. Bleeker, C J 1973. Het geheim van de godsdienst. Theologia evangelica 8/1, 67-68.

1975. Facelina, R 1973. Liberation and salvation. Theologia evangelica 8/1, 6667.

1977. Turner, H W. Rudolf Otto: The idea of the holy: A guide for students. Theologia evangelica 10/1, 87-88.

1979. Tremmel, W C 1976. Religion: What is it? HTS 35/1 \& 2, 131.

1979. Verhoeven, C W M et al 1979. Dood en stervensbegeleiding. HTS $35 / 1$ \& $2,132$.

1980. De Vos, P J 1978. Die sosiale denke van die ou Grieke en Romeine. HTS 36/1 \& 2, 82-83.

1980. Van Bruggen, J 1978. Het huwelijk gewogen. HTS 36/3 \& 4, 109-110.

1980. Bosch, D J 1979. Heil vir die wêreld. HTS 36/3 \& 4, 113-114.

1982. Simpson, C J A 1982. Ek en my medemens. Die Hervormer 74/8, 14.

1984. Bouman, J 1980. Das Wort vom Kreuz und das Bekentniss zu Allah. HTS 40/2, 162-164.

1984. Krüger, J S 1981. Studying religion. HTS 40/2, 177-178.

1984. Vorster, W S (red) 1983. Church and industry. HTS 40/2, 195-197. 
1989. Krüger, J S 1988. Aandag, kalmte en insig. HTS 45/1, 215-216.

1990. Van der Walt et al 1990. Die 'New Age'-beweging. Die Henormer 82/22, bl 6 .

1991. Van der Walt et al 1990. Die 'New Age'-beweging. HTS 47/2, 560-562.

Briewe

1984. Onverdraagsaamheid? Die Hervormer 76/2, bl 13.

1984. Moslemteken op voedsel. Prof Van der Merwe antwoord soos volg. Die Hervormer 76/6, bl 13.

1987. Nederduitsch Hervormde Kerk in die oë van al sy lede. Die Hervormer $79 / 4$, bl 6 .

Referate en adviesstudies

1978. Bonusverdedigingsobligasies - nogeens 'n verantwoording. Notule Kommissie AKV, Augustus 1978, Bylae N.

1978. Het die kerk 'n taak ten opsigte van volksidentiteit? Studie vir Artikel IIIstudiekommissie (1978-1980).

1979. Nuwe ontwikkelinge op die gebied van die Godsdienswetenskap. Voordrag voor die Predikantevergadering.

1988. Die algemene/katolieke Christelike kerk, individuele kerke en kerkgenootskappe. Studie vir die Studiekommissie Artikel III (1986-1989).

1988. Kommentaar op sekere artikels en bepalings van die Kerkwet na aanleiding van die volkskerkgedagte. Studie vir die Studiekommissie Artikel III (19861989).

1990. Aanhef tot die Grondwet van 1984. Notule Kommissie AKV, Junie 1990, Bylae L. 